\section{INTES'TINAL TYPES.}

The various intestinal neuroses, nervous diarrhea, mucous colic and atonic and spastic constipation are frequently found to be due to the ingestion of insufficient nourishment. This is the one dictetic plan that is rarely suggested for these conditions, but is most often of value, as it removes the causative condition while other plans depend on blandness to quiet or irritation to stimulate peristaltic activity. The patient is apt. to learn, after months of suffering, that a choice of food makes comparatively little difference in these neuroses, and andinits complete disconragement. If the condition is due to underfeeding, the ingesting of a generous dict and one chosen with comparatively litile regard to stimulation or seclation of peristaltic activity soon shows remarkable results.

(Thronic catarrhal conditions of the bowel are frecuently eomplieated by functional disturbances from underfeeding, and the apparent failure in the treatiment of some cases of colitis may be attributed to the oversight of this complication.

\section{ANFMI: TYPW.}

Although we have long known how little iron was needed by the body and how small were the daily losses compared with the iron content of almost any diet capable of sustaining life, we have continued to administer iron to the individual with hemoglolin helow the avernge, and have constantly been on the alert to find a more efficacious form of this element. We have no rouson to suppose that the red cells have the first call on the ingested proteid for use in the making of hemoglobin. A deficiency of available proteid means deficieney of hemoglobin, whether the deficiency be due to failure of proper intake or to the abnormal destruction of the ingested proteids. I am convinced that we should have these two possililities in mind in every case of simple anemia. In the alsence of those pathological conditions known to affect dissipation of energy or tissue destruction we may find, then, either a diet deficient in total nutrients but abundantly rich in proteid which is used up as a fuel food, or a diet markedly poor in proteids although little below the standard in total nutrients.

Amone young children, school girls and young women there is a large number who owe their anemia to this kind of underfeeding. Some have an aversion to all albuminous foods and are overfond of fruit and candy. Others have no particular aversions, but eat little of anything. The resulting anemia is not evideneed alone by the color or estimation of hemoglobin, but often leads to attacks of faintness, dyspnea on exertion, palpitation of the heart, anemic hemorrhages and other symptoms of the true anemic state. Many of these cases have no nervous symptoms or actual gastro-intestinal disturbances. The condition of anemia has usually been recognized by all their medical advisers and iron in all its various forms administered for months. The reply to absolute and strict regulation of the diet is very rapid, if underfeeding is the true cause of the anemia. In every case of simple anemia without. discoverable organic cause, this is the rational line of therapy.

\section{NIERVOUS TYPLS.}

The management of the elass of comclitions spoken of as the neuroses presents the most difficult of medical problems. 'Their e(omplete understanding requires more knowledge than we possess of the psychic functions and their relation with the physical body. We are almost necessarily led into the maze of metaphysical speculation. Fundamental differences of opinion seem unavoidable. Formerly all trentment was physical, while to-rlay the pendulum is swinging in the other direction. It seems impossible to deny the mutual interdependence of the mind and the body. It is only in rare instances that we fail to see subversion of the higher mental faculties in depleted physical conditions. Practically it is observed that the so-called neuroses and poor general nourishment usually go hand in hamd. Many have called attention to the almost universal habit among this class of individuals of eating less food than their stronger neighbors. Emphasis has usually been laid on the necessity of rest and "overfeeding " when the condition of neurasthenia or nervous exhaustion is reached. No doubt this type is more in need of raclical treatiment, but all about us are numbers of poor forlorn individuals living in a state of semiinvalidism, possibly able to work, but contimually afflicted with "nerves"; with easily developed mental and physical fatigue, headaches and backaches, vertigo and nausen, insommia and depression of spirits, all manner of aches and pains and disturbances of function. Some owe their condition purely to mental habits, but experience soon teaches that a stronger mind and a less irritable nervous system naturally follows an improvement in nutrition. In an astonishing number of instances a restoration to usefulness and health follows the ingestion of proper foods. The institution of the proper habits is the difficult, problem to be worked out in each individual case; the tact and resourcefulness of the therapentist. are taxed to the uttermost. Harmful autosugraestions must be combated by reason and hy encouraging sugrestions. It is in this direction that our work as practitioners is hroadening out. We are learning to treat not the body, but the whole man.

\section{IMMUNITY ANI) THERAPIEUTIC ACIIION.}

BY THOMAS J. MAYA, А.M., M.n., PHILADVI,HA, PA.

Brumer in the existence of a principle that protects the animal organison against discase and injurious influences is coeval with the history of medicine. 'The vis medicatrix natura of Hippocrates, the archwus of Paracelsus, and the vital spirit of van Helmont, were but various expressions of this faith. The fact that typhoid fever, smallpox, yellow fever and many other diseases 
protect against second attacks is a practical verification of this prineiple. 'The use of tobacco is another example of this. The novitiate becomes intoxicated and violently nauseated when he first begins to smoke or chew, which in the course of a short time passes off, never to reappear so long as the habit is maintained. A similar immunity to injurious influences prevails throughout the vegetalole lingdom.

In what does this immunity consist, and what, is its possible explanation? If one answer stands out more clearly than another, it, is that it is not. " guarding "spirit," or an " entity," which is separate from, and independent of, the normal physiologic processes of the hody, as was believed in Former days; but that it, constitutes an integral and essential part of living matter. Spencer has defined life, proximately, as an organism which maintains its moving ecquilibrium by forces acting from within and from without; and in keeping with this definition, let us make a crude comparison between this moving mass and a spinning top. A top continues its moving equilibrium until it is overcome by the antagonistic action of external incidental forces. Now an antagonistic incidental force brings alhout one of two results. It either overthrows the top and brings its moving equilibrium to a premature end, or it interferes with it to such a degree that it will have to readjust itself to a new and an altered moving equilibrium. The same holds true of living matter. The unfriendly forces that disturb but do not destroy its moving equilibrium end their effects in establishing an altered equilibrium which still belongs to the confines of health. 'The toxic effects of tohacco, for example, establish a constitutional condition different from that which obtained before this agent was taken, hring about a readjustment of the bodily forces, and produce a toleration for quantities of this drug, which in the beginning provoked such disastrous results. Nor is there striking evidence that, if used in moderation, it produces any perceptible harmful action in the great majority of those who indulge in it. Seasickness, a disorder of the nervous system with a well recognized pathology, caused by the mechanical motion of ocean vessels, is another instance in which readjustment, of bodily conditions conform to the action of hurtful external influences. Very few people who go on long sea voyages are entirely exempt from this disease, yet a single pronounced att tack will give them immunity from it so long as they follow the sea. Both tobaceo poisoning and seasickness are examples, then, in which bodily conditions have been forced to rearrange themselves into other but also normal attitudes, by the influences of unfriendly external forces, and there is no doubt that these results represent, a broad general physiologic truth which underlies many other similar phenomena, like those of smallpox, yellow fever, typhoid fever, measles, scarlatina, etc.

What, then, is the nature of this immunity? What is its mechanism, and where is its location? (ireat efforts have been made in recent years to show that it consists of a process known as phagocytosis - a process in which the leucocytes of the body are supposed to be engaged principally in the special work of attacking and of devouring pathogenic organisms, and which is designilted as a warfare against disease. 'That phagocytosis exists in the borly is true, but, whether its physiologic: function consists in waging special wat? against disease is a different thing. Its element is a leucocyte in activity, possessing the chararteristies of other unicellular organisms, riz., of enveloping fraginents of blood cells, of musceular and elastic fibers, of fat and pigmentary cells, of dust, bacteria and other foreign bodies, and of clisintegrating them.

Viewed from any standpoint that it may be, there is no doubt that the function of phagocytosis is that which is exercised by leucocytes everywhere, and plays a very imporlant part in the nutritive processes of the body, hut the effort to compel it to assume the special and unnatumal province of a disease-destroyer is, notwithstanding its present notoriety, too nebulous to require serious reflection. One of the highest authorities on pathology in Germany states that to define this process, the function of which is to absorb nutritive material, as a warfare against the causes of diseases, does not, even lise to the dignity of a poetic conception of this phenomenon. ${ }^{1}$

It scems to the writer that by far the more feasible explanation of the genesis of immunity rests on purely physical principles. When (wo forces of unequal strength eome in contact with one annther, the stronger eauses the weaker to move in a direction parallel to its own, and to a point, where a mutual balance takes place; and although the latter may tend to relound and to assume its former position, yet through the continuous operntion of a series of such impacts, it, will finally be forced to seek a new or another state of equilibrium, in which it will remain after the attacking force has ceased to aet.

When a violent storm descends on a forest, earh tree, individually and collestively, is fored to hear the brunt of the battle. The more unprotected. the older and feebler, trees and the weaker and more exposed branches of the rounger and stronger trees, will he the first to gor down in the onslaught. liven the strongest, will he put to the severest test, and only those remain which possess the reserve power to fully react against the storm's fury. Every individual surviving tree is neressarily fored into annther and a stronger equilibrium; and collectively, owing to the strain and furious ordeal to which it was subjected, and to the weeding out of many of its encumbering elements, the forest is physically stronger, less vulnerable, and far more ahle to withstand and resist a seend attack of the same kind, than it was hefore. In other words, the forest is immune. to another similar assault, and will remain so

1. Win Vorgang (phagocytosin), der die Aufuahme von Nahrungsmaterial bezweekt, als einen Kumpe zul bezcielunon, ist nicht

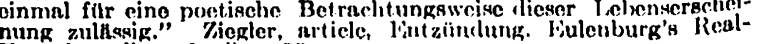
nung zultssig." " Tiegler, nrt
Fincyclopiedie, vol. vii, p. 88 . 
until time and circumstance undermine its stalility.

'The reaction between bodily tissues and the impact of external or internal incidental forees is, in effect, the same as that which takes place between the forest and the storm. 'Thus the effects of a slight blow are rendily overeome; but the shock of severe injury is offen grave enough to disturb the bodily equilibrium to such a degree that reaction is impossible, and death is the consequence. $A$ strong and healthy body is much less liable to contract disease than one which is already patrly broken down. Mortification and gangrene are more prone to follow wounds and injuries in individuals with depraved health, than under opposite and more favorable conditions. Wounds heal more rapidly and kindly in strong than in weak bodies. 'The same conflict between health and disease is witnessed in chronic ulcers, where the line between health and disease advances and recedes, causing the ulcer to appear large at one time and small at another, in direct correspondence with the strength and weakness of the part, and it is a noted fact that the line of treatment which is pursued universally is that of endeavoring to maintain the local and general resistance of the body. In threatened invasion of mortification, or of gangrene, the early application of stimulating poultices will sometimes avert the langer, or at least, tend to circumseribe the proeess, and limit it to a smaller area than if left to its mirrestricted course.

'The vis medicatrix natura is, therefore, in all probability, an innate protective property of all tissues - a part of their very physiologic constitution, and does not, reside in any separate special mythical or supposed real entity. Perhaps the most exact demonstration of the truth that this power of organic reaction or resistance is located, at least in the muscular tissue, and that it may he enhanced by or interfered with hy drug-action, is found in the following graphic; record given by the isolated frog's heart, under the influence of blood, curare and chloroform. 'Thus it has been discovered that curare 1: 80,000 , $i$. $e$, one part of curare to eighty thousand parts of. $2 \%$ solution of blood, will produce the first series of tracings given in the illustration below. These tracings are slightly higher than those which hlood alone is able to produce, as has been repeatedly proven. If, immediately after the curare tracings have been obtained, the heart is subjected to chloroform, 1: 500, $i$. e., one part of chloroform to five hundred parts of $2 \%$ bloodsolution, the second series of tracings is produced. Now, if after this a $2 \%$ solution of blood containing the same proportion of curare and chloroform, $i$. e., one part of curare to eighty thousand, and one part of chloroform to five hundred parts of $2 \%$ blood-solution, is transfused through the heart, the third series of tracings is obtained.

in: What is the interpretation of these phenomena? First, the tracings which the heart is able to give with blood alone (not shown in the illustration), and which are slightly lower than those given by curare, in the proportion of $1: 80,000$, must lie

taken as a stanclard of the normal strength or resistance of the heart muscle. Second, the tracings which are given by curare, 1: $80,00()$, demonstrate that this dose of curare is capable. of increasing the heart's strength or resistance over and alove the point which blood is capable? of giving alone. 'Third, ahloroform, 1:500, depresses or almost entirely overcomes the heart's resistance or reaction, which is shown in the di-

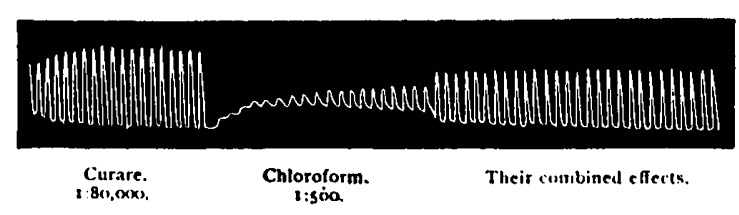

minutive and deporessed trarings; and, fourth. it is demonstrated that by rombining curare in the proportion of $1: \mathrm{s}(0,0)(0)$ with ehloroform 1:500 - the same doses which separately produced the first and second series of tracings the eurare dose will reinforec the physiologic: resistance or reaction of the heart muscle to such a degree that it is enabled to suceessfully antaugonize and almost wholly throw off the disinteglating effects of the chloroform dose, as is wit nessed in the third series of tracings, which are nearly as high as the first series. In other words. the conflict between the two drugs is not a chemieal, but a physical one, in which the heart musele is simply the medium through which the stimulating inflience of curale and the depressing effects of chloroform are enabled to display their antagonistic: powers when properly adjusted.

That which is true of the antagonism between curare and chloroform is also found to be true of that of the following named drugs:

\begin{tabular}{|c|c|c|}
\hline \multicolumn{2}{|r|}{$\begin{array}{c}\text { Names of drugs and their dilutions with } \\
2 \% \text { bloud-solution. }\end{array}$} & $\begin{array}{l}\text { Elevations of } \\
\text { tracings in } \\
\text { millimelers. }\end{array}$ \\
\hline 1. & $\begin{array}{ll}\text { Atropine, } & 1: 160,000 \\
\text { Aleohol, } & 1: 25 \\
\text { Siflects of their combined action, }\end{array}$ & $\begin{array}{r}13 \\
4 \\
8\end{array}$ \\
\hline II. & $\begin{array}{ll}\text { Aeonitine, } & 1: 160,000 \\
\text { lither, } & 1: 5 \\
\text { liffects of their combined action, }\end{array}$ & $\begin{array}{r}15 \\
5 \\
10\end{array}$ \\
\hline JII. & $\begin{array}{l}\text { ('urare, } \\
\text { lither, } \\
\text { liffects of their combined netion, }\end{array}$ & $\begin{array}{l}18 \\
18\end{array}$ \\
\hline IV. & $\begin{array}{ll}\text { Atropinc, } & 1: 160,000 \\
\text { l'ther, } & 1: 10 \\
\text { liffects of their combined action, }\end{array}$ & $\begin{array}{r}10 \\
7 \\
10\end{array}$ \\
\hline V. & $\begin{array}{ll}\text { Alropine, } & 1: 160,000 \\
\text { Chloroform, } & 1: 500 \\
\text { Effects of their combined action, }\end{array}$ & $\begin{array}{l}8 \\
2 \\
9\end{array}$ \\
\hline VI. & $\begin{array}{lc}\text { Curare, } & 1: 80,000 \\
\text { Chloroform, } & 1: 500 \\
\text { liffects of their combined action, }\end{array}$ & $\begin{array}{r}12 \\
3 \\
9\end{array}$ \\
\hline VII. & $\begin{array}{ll}\text { Aconitine, } & 1: 160,000 \\
\text { Chloroform, } & 1: 500 \\
\text { Filfects of their combined action, }\end{array}$ & $\begin{array}{r}16 \\
4 \\
15\end{array}$ \\
\hline V1II. & $\begin{array}{lc}\text { Strychnine, } & 1: 160,000 \\
\text { Chloroform, } & 1: 500 \\
\text { Sifects of their combined action, }\end{array}$ & $\begin{array}{r}14 \\
9 \\
15\end{array}$ \\
\hline
\end{tabular}




\begin{tabular}{|c|c|c|c|}
\hline \multicolumn{3}{|c|}{$\begin{array}{l}\text { Names of drugs and their dilutions with } \\
2 \% \text { blood-eolution. }\end{array}$} & $\begin{array}{c}\text { Llevations of } \\
\text { trueings in } \\
\text { millimeters. }\end{array}$ \\
\hline $\mathrm{IX}$ & $\begin{array}{l}\text { Aconitine, } \\
\text { Curare, } \\
\text { Liffects of their }\end{array}$ & $\begin{array}{l}1: 160,000 \\
1: 26 \\
\text { mbined action, }\end{array}$ & $\begin{array}{r}16 \\
5 \\
15\end{array}$ \\
\hline X. & $\begin{array}{l}\text { Atropine, } \\
\text { Strychnine, } \\
\text { Liffects of their }\end{array}$ & $\begin{array}{l}1: 160,000 \\
1: 1,000 \\
\text { mbined action, }\end{array}$ & $\begin{array}{r}15 \\
4 \\
14\end{array}$ \\
\hline XI. & $\begin{array}{l}\text { Strychnine, } \\
\text { Atropine, } \\
\text { Effects of the }\end{array}$ & $\begin{array}{l}1: 160,000 \\
1: 1,000 \\
\text { mbined action, }\end{array}$ & $\begin{array}{r}17 \\
4 \\
15\end{array}$ \\
\hline
\end{tabular}

Several things are made very clear by the preceding considerations. One is, that drugs expend their forces direstly on the bodily textures, and not on any hypothetical intervening medium. Another is, that small or minimum doses enhance boclily resistance, and that large or maximum closes depress or paralyze the same. And still another is, that minimum doses successfully antagonize the disintegrating effects of maximum closes. 'These antagronistic effects are displayed here as decidedly as if they had been wrought ly the t,we mechanical forces of attraction and repulsion, and they give us an exact mathematical demonstration of the power which drugs have of supporting and preserving life when attacked by adverse forces. Now, if we recognize the fact that discase is but the manifestation of forces which move in a direction adversely to health, and substitute these for the operation of the inaximum drug doses in the above illustrations, do we not have a clear picture before us, as to how a large class of drugs in minimum doses combat disease, viz., hy stimulation? On the other hand, is it not equally clear how maximum doses possess the property of depressing hyperactivity of the bodily textures - a pathologic condition which lies at the bottom of many important diseases and thus give us at least a fundamental idea of the action of two other large classes of drugs, viz., antiscptices and antipyretics?

\section{DIAGNOSIS ANI) TREATMENT OF DIPH- 'THEIRIA IN YOUNG CHILDREN.*}

BY F. P. WLBETER, M.1., Instructor in Discases of Children, Medical School of Maine, Bowdoin
Collegc, I'ortland, Me.

THis paper is not intended to be a complete consideration of the diagnosis and treatment of diphtheria in young children. It deals with diagnosis particularly in young children, because it is among them that most cases occur, and more especially because the younger the child, the higher the mortality and the greater the urgency of diagnosis and treatment. Moreover, since the general use of antitoxin, the mortality in the very young has not been reduced proportionately to that in older patients.

In making a diagnosis of diphtheria, we have two methods: the bacteriological and the clinical.

The bacteriological method is subdivided into immediate examination of smears and late examination of cultures.

Diagnosis by smears is unreliable, as when

* Inad to the Portland Modical Club, June 6, 1907. smears show no bacilli, bacilli may be shown by culture. By a smear you can only note the presence or absence of bacilli, like the Klebs-Löffler. However, this direct method is suggestive or corroborative when positive, but when negative should be disregarded entirely.

The examination of cultures is the most certain method we have of diagnosticating diphtheria. 13ut is this as valuable a method for purposes of treatment as the clinical diagnosis?

In recent years laboratory diagnosis has properly acquired a high position in the minds of most physicians, but I believe, in the estimation of of many, its position is too exalted. I have had sufficient experience in the midst of laboratory diagnosis to know that it has some fallacies. Aside from the possibility of crror, bacteriological diagnosis must use up valuable time; in the case of diphtheria, probably, twelve hours or more. Can we afford this time for purposes of treatment? Clinically, by certain symptoms and signs familiar to us, we can usually recounize a probable case of diphtheria. There is quite a possibility of mistake; still, bacteriological examinations have generally shown earlier clinical diagnoses to have been correct.

I believe that textbooks in their discussion of diphtheria mislead. They follow the old rule of etiology, pathology, symptomatology, diagnosis, prognosis and treatment, particularly, treatment follows diagnosis. For diagnosis they teach you to rely upon cultures. Here, it seems to me, is a disease in which, especially in young children, treatment should come first upon suspicion. Then positive diagnosis should follow for purposes of quarantine. In the hands of the general practitioner, the reliance upon culture examinations has a damaging effect upon treatment. A physician may be reluctant to make a diagnosis of diphtheria. He may feel that he is working in the interest of his patient, or the family of the patient, to avoid quarantine if possible; to wait for the report of the culture, hoping that it may be negative. He feels justified in such delay because he follows the instruction of the books. He knows that laboratory diagnosis is the surer diagnosis. He knows that his two best diagnostic aids are, first, the report of the culture; second, the spread of the membrane.

In medicine it is good to feel certain; perhaps in a dozen hours one can read, " J)iphtherial bacilli found," or can note the visible spread of membrane, although the invisible spread of toxins has been vaster. One then has diagnostic; security; the child has less chance of recovery. I believe that the proportionately high mortality of diphtheria in young children is due in part to reluctance to call certain suspicious cases diphtheria and to institute quarantine. An oller patient can naturally better tolerate such delay.

We, as practitioners, want the earliest possible diagnosis, because the cases treated earliest have given much the best results. Then, too, isolation and immunization are more certainly accomplished.

Diphtheria antitoxin has been shown to be 